\title{
ARFIP1 wt Allele
}

National Cancer Institute

\section{Source}

National Cancer Institute. ARFIP1 wt Allele. NCI Thesaurus. Code C114682.

Human ARFIP1 wild-type allele is located in the vicinity of $4 \mathrm{q} 31.3$ and is approximately 139 $\mathrm{kb}$ in length. This allele, which encodes arfaptin-1 protein, may play a role in vesicular transport. 